\title{
EFFECT OF FLOW-RELATED SUBSTRATE ALTERATION ON PHYSICAL HABITAT: A CASE STUDY OF THE ENDEMIC RIVER LOACH SINOGASTROMYZON PULIENSIS (CYPRINIFORMES, HOMALOPTERIDAE) DOWNSTREAM OF CHI-CHI DIVERSION WEIR, CHOU-SHUI CREEK, TAIWAN
}

\author{
FU-CHUN WU ${ }^{\mathrm{a}} *$ and CHI-FANG WANG ${ }^{\mathrm{b}}$ \\ a Department of Bioenvironmental Systems Engineering and Hydrotech Research Institute, National Taiwan University, Taipei 106, \\ Taiwan, ROC \\ b Department of Bioenvironmental Systems Engineering, National Taiwan University, Taipei 106, Taiwan, ROC
}

\begin{abstract}
This paper addresses the variation of substrate status with flow in the framework of habitat simulation. The Physical Habitat Simulation System (PHABSIM) was developed as a tool for water management and has become one of the most popular methods worldwide. Despite its many advantages, the variation of channel properties with flow is not addressed in PHABSIM. We modified PHABSIM by incorporating a sub-program that can perform substrate analyses under five different schemes for evaluating the substrate suitability. These schemes include the conventional methods to specify the substrate attribute (scheme 1) and to use the mean grain size of the original bed material for determining the substrate suitability (scheme 2), or employ the threshold conditions for sediment entrainment to evaluate the nominal grain size of the stable substrate (schemes 3-5). As a case study, Sinogastromyzon puliensis in Chou-Shui Creek (Taiwan) is selected as the target species for the habitat simulation. For schemes 1 and 2, the substrate attribute specified for each cell of a cross-section does not change with flow. The nominal grain size of the stable armour material (scheme 5) is generally greater than the nominal grain sizes of the above-critical bed material (scheme 3) and the static armour layer (scheme 4). The simulation results indicate that the suitability values specified in scheme 1 and the resulting habitat area are on the optimistic side, whereas scheme 2 tends to undervalue the suitability of the hydraulically worked substrate. The overall variation trends of the weighted usable area (or percentage usable area) curves for different substrate schemes are similar, especially in the in-phase regions of the water velocity and depth. The results of this study appear to imply that the flow-related habitat analyses are not usually sensitive to substrate. Copyright () 2002 John Wiley \& Sons, Ltd.
\end{abstract}

KEY WORDS: physical habitat simulation; habitat suitability criteria; instream flow; substrate attribute; sediment entrainment; armour layer; bedload; weighted (percentage) usable area

\section{INTRODUCTION}

The Physical Habitat Simulation System (PHABSIM) was developed as a water management tool to assist in the establishment of instream flow requirements for supporting water control and allocation activities (Milhous, 1999). The National Ecology Research Center of the US Fish and Wildlife Service developed a conceptual framework, the Instream Flow Incremental Methodology (IFIM), and released in 1978 the first version of PHABSIM for modelling instream physical habitat. This system was further refined and expanded into a library of models that can perform hydraulic simulation and habitat analyses (Milhous et al., 1989). Despite certain limitations and drawbacks to the application of PHABSIM (e.g. Carling, 1995; Gore and Hamilton, 1996; Milhous, 1999), this system has been widely recognized and become one of the most commonly used methods in North America (Reiser et al., 1989). It has also been gaining acceptance in Europe (FAO, 1998).

\footnotetext{
* Correspondence to: Fu-Chun Wu, Department of Bioenvironmental Systems Engineering and Hydrotech Research Institute, National Taiwan University, Taipei 106, Taiwan, ROC. E-mail: fcwu@hy.ntu.edu.tw
} 
The PHABSIM consists of two sub-systems, namely, hydraulic and habitat simulation programs. The hydraulic model simulates the water surface levels and velocity distributions of the stream cross-sections for each discharge of concern. These results are then incorporated with the habitat suitability curves specified for a life stage of a particular species to evaluate the usable habitat area corresponding to that flow. Habitat suitability curves are the biological basis of habitat simulations. It has been suggested that the concept of habitat guilds or an indicator species can be applied when considering multiple species with conflicting habitat requirements (Jowett, 1997). The habitat suitability curves commonly concerned in PHABSIM include the preferences of the target species (or target guilds) on water velocity, depth and channel properties. On one hand, the criteria curves for water velocity and depth reflect the assumption that lotic biota have their distribution and certain phases of their life cycles controlled by the hydraulic conditions within the water column (Statzner and Higler, 1986; Petts, 1994). On the other hand, the physical properties of the channel, such as the substrate composition, cover and vegetation must also play important roles affecting the instream physical habitat. A channel index system can be developed specifying the suitability weights to different classes of dominant substrate (such as clay, silt, sand, gravel, cobble, boulder or bedrock), cover availability, and vegetation type (Nestler et al., 1989). The stream cross-section is divided into a number of cells (subareas) for each of which the PHABSIM user assigns the attributes of substrate, cover, and/or vegetation based on the results of field explorations and measurements, or the auxiliary materials (such as aerial photos, vegetation maps, or discharge-stage rating curves). The weighted usable area (WUA) in a stream reach is then evaluated by the formula:

$$
\mathrm{WUA}=\sum_{i}\left[f\left(V_{i}, D_{i}, C_{i}\right) \cdot A_{i}\right]
$$

where $A_{i}$ is the stream area of cell $i ; f\left(V_{i}, D_{i}, C_{i}\right)$ is the combined suitability factor (CSF) for $A_{i}$. Several methods have been proposed to determine CSF but usually a product of the corresponding suitability weights for water velocity, depth, and channel property is employed (Milhous, 1999).

In Equation 1, the water velocity and depth in cell $i$ (i.e. $V_{i}$ and $D_{i}$ ) are the output results of the hydraulic simulation and both vary with discharge. The suitability weights corresponding to these two hydraulic variables are dynamically adjusted with the change of flow condition. However, the physical property of the channel (i.e. $C_{i}$ ) remains invariant once the attributes of the cells are specified. That is, the variation of channel properties with flow is not addressed in PHABSIM. For example, the grain sizes of the sediments entrained by the bed shear stress can be considerably different under various flows. As a result of the streambed mobilization, the dominant grain size of the stable substrate that may serve as the potential habitat of the instream biota will change. Thus the corresponding substrate suitability needs to be modified to reflect the change in the dominant grain size. It has been pointed out that the change of substrate status with flow should be taken into consideration for improving the current physical habitat simulation (Milhous, 1999). The objective of this study is to provide a conceptual framework for investigating the effect of flow-related substrate alteration on physical habitat. To this end we modify PHABSIM by incorporating a sub-program that can perform substrate analyses under various schemes. The proposed framework is applied to a case study on a Taiwanese endemic species downstream of Chi-Chi diversion weir in Chou-Shui Creek, Taiwan. The construction of the diversion weir upstream changes the flow and sediment regime downstream, thus we are trying to determine the instream flow requirement under a new sediment regime. The first step toward such a task would be evaluating the composition of stable substrate, which will be described in the next section.

\section{METHODS}

To determine the substrate composition for habitat evaluation, one needs the threshold condition for sediment entrainment or the composition of the stable substrate. Three methods are used herein, namely, (1) critical grain size for incipient motion, (2) grain size distribution of static armour, and (3) maximum bedload size in partial armour. For these methods, it is assumed that the final predominant substrate in the river would be (1) particles greater than the critical grain size, (2) mean size of the predicted armour size distribution, 
and (3) particles greater than the maximum bedload size transported, respectively. The details are given subsequently.

\section{Critical grain size for incipient motion}

Iwagaki (1956) developed a theory of incipient motion for well-sorted sediment by considering the force balance of the spherical particle and the sheltering effect caused by others. Iwagaki expressed the theoretically derived threshold condition in an empirical form. His result, compatible with the widely used Shields (1936) curve, can be expressed as:

$$
\left\{\begin{array}{l}
\tau^{*}=0.05 \text { for } R^{*} \geq 671 \\
\tau^{*}=0.00849\left(R^{*}\right)^{3 / 11} \text { for } 162.7 \leq R^{*} \leq 671 \\
\tau^{*}=0.034 \text { for } 54.2 \leq R^{*} \leq 162.7 \\
\tau^{*}=0.195\left(R^{*}\right)^{-7 / 16} \text { for } 2.14 \leq R^{*} \leq 54.2 \\
\tau^{*}=0.14 \text { for } R^{*} \leq 2.14
\end{array}\right.
$$

where $\tau^{*}=\tau_{c} /\left(\gamma_{s}-\gamma\right) d, \tau_{c}=$ critical shear stress, $\gamma$ and $\gamma_{s}=$ specific weights of water and sediment respectively, $d=$ particle diameter, $R^{*}=\sqrt{\left(\gamma_{s} / \gamma-1\right) g d^{3}} / v, g=$ gravitational acceleration, $v=$ kinematic viscosity of water. When $\tau_{c}$ is replaced by the applied bed shear stress $\tau_{0}(=\gamma D S)$, the corresponding critical size $d_{c}$ can be determined through the numerical iterations, where $D=$ water depth, $S=$ water surface slope. Natural streambeds are composed of non-uniform materials for which the hiding and exposure effect among the particles substantially influences the critical shear stress of each size fraction (e.g. Wu et al., 2000). Many researchers have addressed such an effect by a relative-size correction factor (see summary by Bridge and Bennett, 1992). However, in this study we have applied results from studies with uniform sediment without any modification for the hiding (relative-size correction) factor.

\section{Grain size distribution of static armour}

Gessler (1970) measured the grain size distributions of the eroded material and the static armour layer to investigate the probability that grains of a specific size will stay on the bed surface. He found that the probability for a sediment particle to stay is related to the ratio between critical and applied shear stresses, $\tau_{c} / \tau_{0}$. For a given grain size, the corresponding critical shear stress $\tau_{c}$ can be immediately determined with Equation 2. The probability for a particle of size $k$ to stay can be expressed as the cumulative probability function of the standard normal distribution:

$$
p(\xi)=\int_{-\infty}^{\xi} \frac{1}{\sqrt{2 \pi}} \exp \left(-x^{2} / 2\right) d x
$$

where $x$ is a dummy variable; $\xi=\left(\tau_{c} / \tau_{0}-1\right) / 0.57, \xi$ varies as a function of $k$ because $\tau_{c}$ is grain-size specific, thus $p(\xi)$ can be alternatively designated as $p(k)$. The grain size distribution of the static armour layer is then evaluated by:

$$
F_{a}(d)=\frac{\int_{d_{\min }}^{d} p(k) \cdot f_{o}(k) d k}{\int_{d_{\min }}^{d_{\max }} p(k) \cdot f_{o}(k) d k}
$$

where $F_{a}(d)=$ cumulative probability function of the grain size distribution of the static armour; $f_{o}(k)=$ probability density function (p.d.f.) of the grain size distribution of the original bed material; $d_{\min }$ and $d_{\max }$ are the minimum and maximum grain sizes of the bed material, respectively. It has been reported that Gessler's method tends to underpredict the grain sizes of the static armour (Sutherland, 1987), and a modified method (Shen and Lu, 1983) has been proposed to account for the effects of non-uniform sediment and fluctuating shear stress. However, due to the complexity of the modified method and the limited extent of improvement, the 
method proposed by Shen and $\mathrm{Lu}(1983)$ is less attractive in the practical applications. Hence the procedures suggested by Gessler (1970) are used in this study to evaluate the grain size distribution of the static armour.

\section{Maximum Bedload Size in Partial Armour Layer}

When the static armour layer is not yet well formed or there is upstream sediment supply in a gravel-bedded river, a partial (or mobile) armour layer will be present at the bed surface (Parker and Sutherland, 1990). For such a case the bedload particles move through or overpass the partial armour (Sutherland, 1987). Based on the data of equilibrium partial armour collected in Oak Creek, Oregon, USA, Milhous (1998) proposed the following semi-empirical equation for the maximum grain size of the bedload:

$$
\left(d_{\max }\right)_{b l}=\left(d_{50}\right)_{a}\left[\frac{R S}{0.018\left(\gamma_{s} / \gamma-1\right)\left(d_{50}\right)_{a}}\right]^{2.85}
$$

where $\left(d_{50}\right)_{a}=$ median grain size of the armour, which can be evaluated with Equation $4 ; R=$ hydraulic radius. Milhous (1998) suggested that Equation 5 should be used only when the median grain size of the armour is greater than that of the bedload. He also pointed out that Equation 5 is valid for the calculation of the maximum bedload size during the partial (or selective) transport but not the full transport of bed material that occurs after the breakup of the armour layer at higher stream flows. Although Equation 5 is site-specific, it provides a practical estimation to the lower limit of the stable substrate.

\section{CASE STUDY}

\section{Study site}

The study site is located in the mid-stream reach of Chou-Shui Creek, middle Taiwan (location map shown in Figure 1). Chou-Shui Creek is the largest river in Taiwan and drains a basin area of $3155 \mathrm{~km}^{2}$. The simulation reach, between Sections 106 and 107, is $897 \mathrm{~m}$ in length with an average slope of 5/1000. The cross-sectional graphs are shown in Figure 2, where the mid-channel gravel bars reveal the braided pattern of the simulation reach. The confined boundaries of the channel are the flood-control embankments. Monthly mean flows summarized from the 1941-1994 records of the Chi-Chi gauging station (5.4 km upstream of Section 107) are listed in Table I, which reveal that the natural stream flows range from 40 to $270 \mathrm{~m}^{3} / \mathrm{s}$ with a mean of $130 \mathrm{~m}^{3} / \mathrm{s}$. However, the data indicate that the majority of daily flows are within the range between 40 and $100 \mathrm{~m}^{3} / \mathrm{s}$, hence the discharges from 30 to $150 \mathrm{~m}^{3} / \mathrm{s}$ are used in the physical habitat simulations. The water surface levels for 30 and $150 \mathrm{~m}^{3} / \mathrm{s}$ and the 10 -year flood $\left(9570 \mathrm{~m}^{3} / \mathrm{s}\right)$ are also illustrated in Figure 2 .

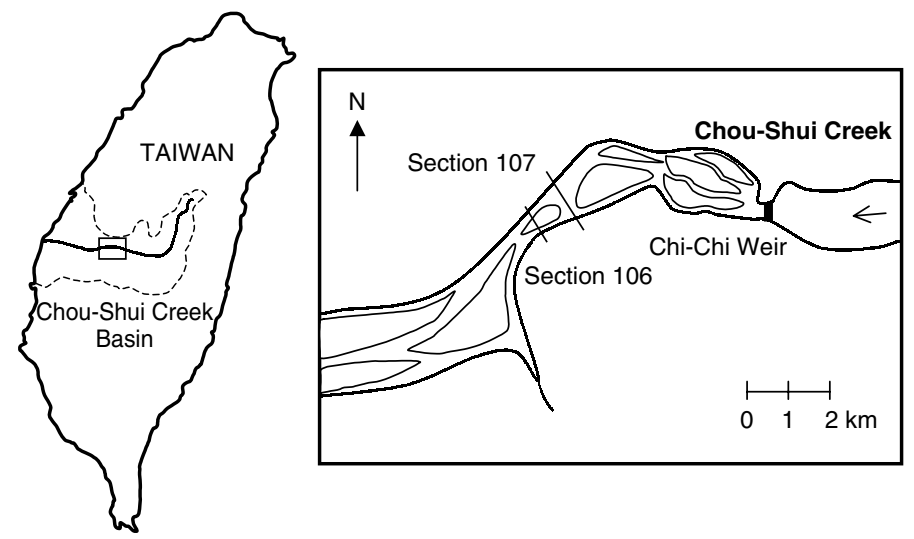

Figure 1. Location map of Chou-Shui Creek basin and simulation reach 

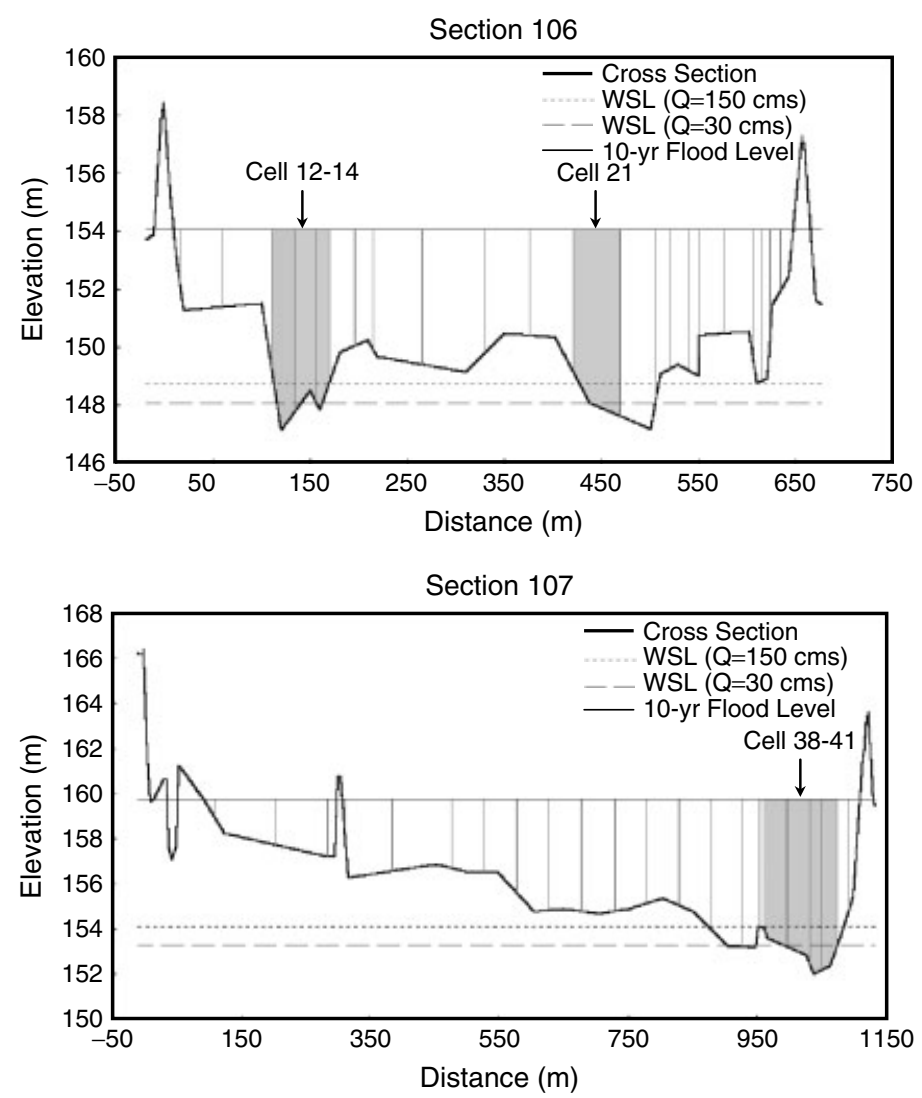

Figure 2. Cross-sectional graphs of Sections 106 and 107 (water surface levels for 30 and $150 \mathrm{~m}^{3} / \mathrm{s}$, and 10-year flood are also illustrated)

Table I. Monthly mean flows $\left(\mathrm{m}^{3} / \mathrm{s}\right)$ of Chi-Chi gauging station (1941-1994)

\begin{tabular}{|c|c|c|c|c|c|c|c|c|c|c|c|}
\hline Jan. & Feb. & Mar. & Apr. & May & Jun. & Jul. & Aug. & Sep. & Oct. & Nov. & Dec. \\
\hline 50.2 & 43.8 & 56.3 & 77.4 & 122.1 & 266.8 & 206.5 & 251.5 & 238.3 & 128.2 & 77.4 & 57.7 \\
\hline
\end{tabular}

The stage-discharge relationships for each cross-section were derived from the reported flows and stages (TPWCB, 1981). The water surface slope was assumed constant over the range of modelled flows.

It was proposed in 1984 to build a diversion weir to meet the expanded demand of water resources for multi-objective uses (i.e. domestic, industrial, and agricultural) in the Chou-Shui Creek basin and its vicinity. The construction of the Chi-Chi diversion weir was initiated in 1993 and is due to be completed in 2001. The design capacity for flow diversion is $160 \mathrm{~m}^{3} / \mathrm{s}$, which results in a possible maximum release of $100 \mathrm{~m}^{3} / \mathrm{s}$ in June. However, if the diverted flow is less than the design capacity, the instream flow release could be larger than $100 \mathrm{~m}^{3} / \mathrm{s}$. The range of modelled flows (i.e. from 30 to $150 \mathrm{~m}^{3} / \mathrm{s}$ ) covers the typical future flow regime downstream of the weir. Flow diversion alters the downstream flow and sediment regime and thus the instream physical habitat. Assessment of the instream flow requirement is among the most important tasks for comprehensive water resources planning. The present study addresses the substrate status corresponding to different instream flow releases. It has been well documented that the entrapment of sediment upstream of a barrier structure (such as weir and dam) and the release of sediment-free water usually cause downstream bed degradation and armouring (e.g. Dietrich et al., 1989; Wilcock and McArdell, 1993; Buffington and Montgomery, 1999). The grain size distribution of the coarse surface layer (either mobile or static armour) 


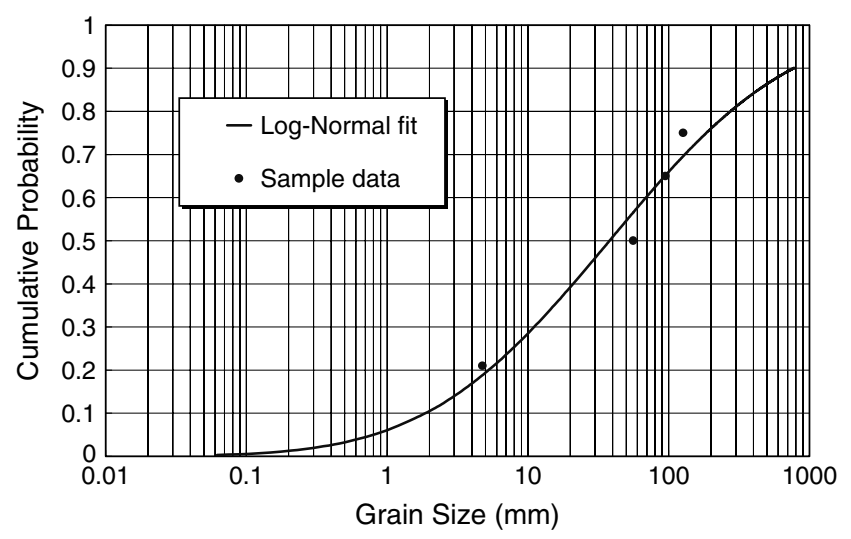

Figure 3. Grain size distribution of original bed material

formed in the downstream reach is dependent upon the flow condition and the composition of the existing bed material (Chin et al., 1994). The original size distribution of the substrate prior to the construction of Chi-Chi weir can be approximated by a lognormal fit to the data of bed material sampled at Section 106 in 1993 (TPWCB, 1996). The lognormal size distribution curve $\operatorname{LN}(3.64,2.35)$ and the sample data are shown in Figure 3. From this cumulative probability distribution, the p.d.f. of the original bed material can be derived.

\section{Target species}

In this study, a Taiwanese endemic species Sinogastromyzon puliensis (locally called 'stone sticker') is selected as the target species for the physical habitat simulation because it has been claimed as one of the endangered species (TESRC, 1996). The fish species Sinogastromyzon puliensis (Cypriniformes, Homalopteridae) has a dark green, flat, plate-shaped body; it inhabits the mid-stream reaches with fast currents, and migrates along the large boulders, feeding on the algae and invertebrates attached to the coarse grains. This endemic species is distributed in the western rivers of Taiwan, mainly in the middle and southern part of the island (for details see Watanabe, 1983). This species has been found in the downstream reach of the Chi-Chi gauge station and a three-year survey programme on its habitat criteria has been implemented (TESRC, 1998). The resulting habitat suitability curves shown in Figure 4 reveal that the favourable water velocity and depth are around $0.45 \mathrm{~m} / \mathrm{s}$ and $0.35 \mathrm{~m}$, respectively. The substrate suitability increases linearly from 10 to $200 \mathrm{~mm}$ and remains unity for greater sizes.

\section{Schemes for evaluating substrate suitability}

Five schemes originating from different perspectives are used herein to evaluate the substrate suitability. The proposed schemes either use the conventional methods to specify the substrate attribute and determine the mean size of the original bed material, or employ the threshold conditions to evaluate the nominal grain size of the stable substrate. These schemes are outlined below.

Scheme 1: specified substrate attribute. This scheme specifies the substrate attribute according to the water surface level of the annual mean flow (i.e. $130 \mathrm{~m}^{3} / \mathrm{s}$ ). The attribute of the substrate in each cell is assigned to one of the following: (1) main channel; (2) stream bank; (3) mid-channel bar; and (4) floodplain. If the substrate of a cell is submerged by the annual mean flow, it is categorized as the main channel. The unsubmerged part within the main channel is categorized as the mid-channel bar. The sloping boundaries adjacent to the main channel are categorized as the stream bank. The remaining part above the water surface level is categorized as the floodplain. The suitability values corresponding to these attributes are 1.0, 0.5, 0.2, and 0.1 , respectively. Establishment of such criteria is empirical, based on the suggestions of the TESRC fish biologists. 

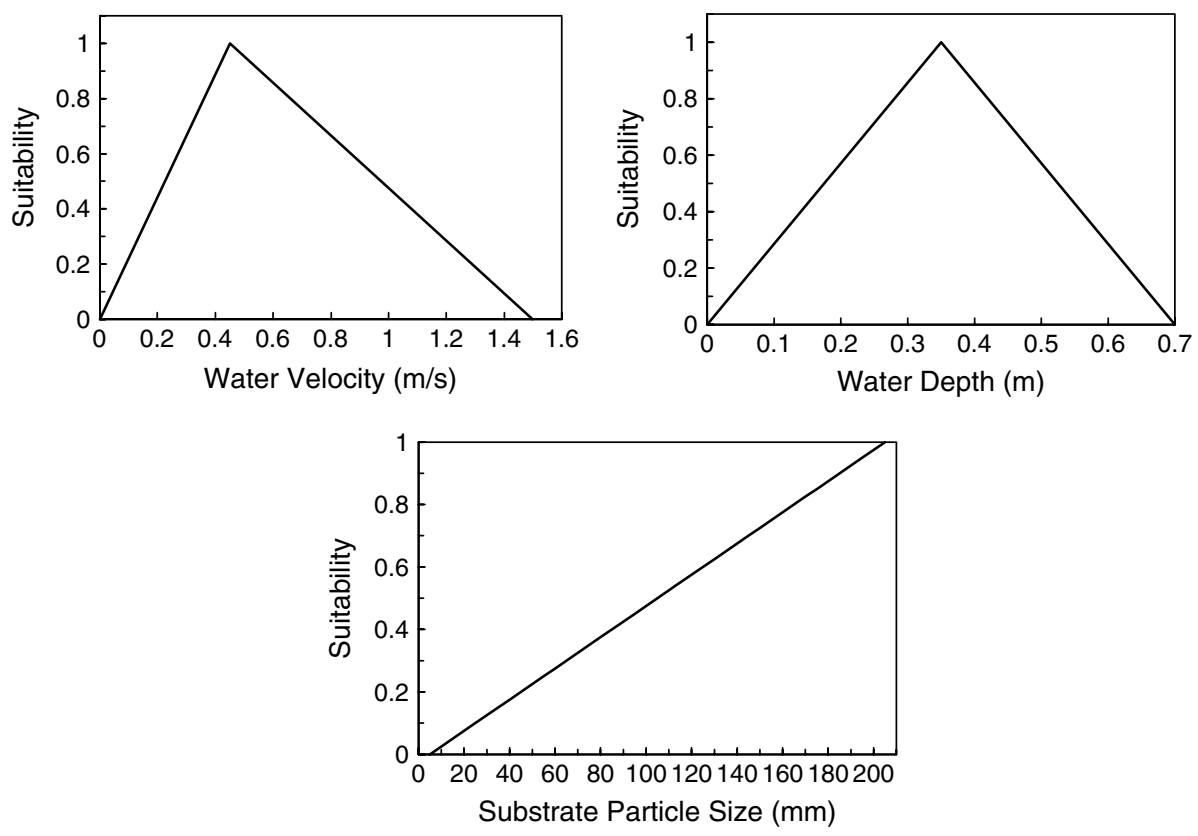

Figure 4. Habitat suitability curves for water velocity, depth, and substrate of target species

Scheme 2: mean grain size of original bed material. This scheme uses the mean grain size of the original bed material to evaluate the substrate suitability. The mean size of the original bed material, $d_{o}$, is determined by

$$
d_{o}=\int_{d_{\min }}^{d_{\max }} k \cdot f_{o}(k) d k
$$

The notation is as defined for Equation 4.

Scheme 3: nominal grain size of above-critical bed material (Iwagaki, 1956). It has been hypothesized in the previous section that the bed material greater than the critical grain size constitutes stable substrate. This scheme uses the nominal grain size of the above-critical bed material to determine the corresponding substrate suitability. In doing so, we removed the lower portion of the original grain size distribution (i.e. for $k \leq d_{c}$ ) to seek the p.d.f. of the above-critical bed material, $f_{a c}(k)$. The nominal size of the above-critical bed material, $d_{a c}$, is then evaluated by:

$$
d_{a c}=\int_{d_{c}}^{d_{\max }} k \cdot f_{a c}(k) d k
$$

A comparison of $d_{a c}$ and $d_{o}$ reveals the coarsening of substrate particles that results from entrainment of fine sediment.

Scheme 4: mean grain size of static armour layer (Gessler, 1970). This scheme employs the mean grain size of the static armour to evaluate the substrate suitability that corresponds to the final stage of streambed armouring. The mean grain size of the static armour layer, $d_{a}$, is calculated by:

$$
d_{a}=\int_{d_{\min }}^{d_{\max }} k \cdot f_{a}(k) d k
$$

where $f_{a}(k)=$ p.d.f. of the grain size distribution of the static armour layer, which is determined through Equation 4. 
Scheme 5: nominal grain size of stable armour material (Milhous, 1998). As mentioned previously, Equation 5 provides a practical means to estimate the maximum grain size of the bedload in a partial armour layer. Under a given flow, the coarser part of the armour material that is greater than the corresponding $\left(d_{\max }\right)_{b l}$ will remain immobile on the bed surface and serves as the stable substrate for the potential instream habitat. As such, the nominal grain size of the stable armour material can be used for evaluating the substrate suitability. The lower portion of the armour-layer grain size distribution (i.e. for $\left.k \leq\left(d_{\max }\right)_{b l}\right)$ is removed to obtain the p.d.f. of the stable armour material, $f_{s a}(k)$. The nominal grain size of the stable armour material, $d_{s a}$, is then calculated by:

$$
d_{s a}=\int_{\left(d_{\max }\right)_{b l}}^{d_{\max }} k \cdot f_{s a}(k) d k
$$

Because Equation 5 was derived from the data of equilibrium partial armour, the present scheme is valid for the case with upstream sediment supply or steady partial transport that has been observed by Wilcock and McArdell (1993, 1997).

\section{RESULTS AND DISCUSSION}

\section{Variation of substrate grain size with flow}

Critical grain size for incipient motion. The relationships between critical grain size and flow are shown in Figure 5, where the variation trends for cells $12-14$ and 21 of Section 106 and cells 38-41 of Section 107 (cells shown in Figure 2) are illustrated, with the corresponding data summarized in Table II. These results reveal that the critical grain size for incipient motion increases monotonically with the flow because both the water depth and the bed shear stress increase with the flow. Cell 13 of Section 106 and cell 38 of Section 107 remain dry when the flows are less than 100 and $60 \mathrm{~m}^{3} / \mathrm{s}$, respectively. Of all the cells, cell 12 of Section 106 and cell 40 of Section 107 have the greatest bed shear stresses in those cross-sections and thus the coarsest critical grain sizes. For the largest simulation flow (i.e. $150 \mathrm{~m}^{3} / \mathrm{s}$ ), the critical grain sizes in these two cells can reach 108 and $139 \mathrm{~mm}$, respectively.

Grain size distribution of static armour layer. Figure 6 demonstrates the grain size distributions of the static armour layers that are developed in cell 21 of Section 106 under various flows. We select this cell for illustration because it experienced considerably diversified water depths in the hydraulic simulations, which in turn correspond to a wide variety of bed shear stress. The results distinctly reveal that the armour layers are coarser grained than the original bed material. Figure 6 also shows that the degree of coarsening increases with flow. For example, the median grain sizes of the static armours formed at $30,60,90,120$, and $150 \mathrm{~m}^{3} / \mathrm{s}$ are $40,95,120,140$, and $150 \mathrm{~mm}$, respectively.

The foregoing argument is further verified by the results shown in Figure 7, where the grain size distributions of the static armour layers developed in cells 12-14 of Section 106 and cells 38-41 of Section 107 are illustrated. For the given flow (i.e. $100 \mathrm{~m}^{3} / \mathrm{s}$ ), it is revealed that the degree of coarsening differs for each cell. The sequences of the curves shown in Figure $7 \mathrm{a}$ and $\mathrm{b}$ are consistent with those demonstrated in Figure 5a and b, respectively. That is, cell 12 of Section 106 and cell 40 of Section 107 have the coarsest armours, whereas the armour layers developed in cell 13 of Section 106 and cell 38 of Section 107 are the finest in grain size. In Figure 7, the median grain sizes of the static armours formed in cells 12-14 of Section 106 are 220, 50, and $150 \mathrm{~mm}$, respectively, while those in cells 38-41 of Section 107 are 100, 180, 240, and $220 \mathrm{~mm}$, respectively. Such diversity in the substrate composition may be a reason for the preference of some aquatic biota for certain habitat patches rather than other hydraulically similar ones with different substrates.

Maximum bedload size in partial armour layer. The relationships between the maximum bedload size and the flow are shown in Figure 8, and the corresponding data are summarized in Table III. The curves in Figures 5 and 8 demonstrate similar patterns, although the variations shown in Figure 8 are much steeper. The data given in Tables II and III indicate that the maximum bedload sizes are generally greater than the critical grain sizes under a given flow. However, we note that this rule is violated when the estimated grain 

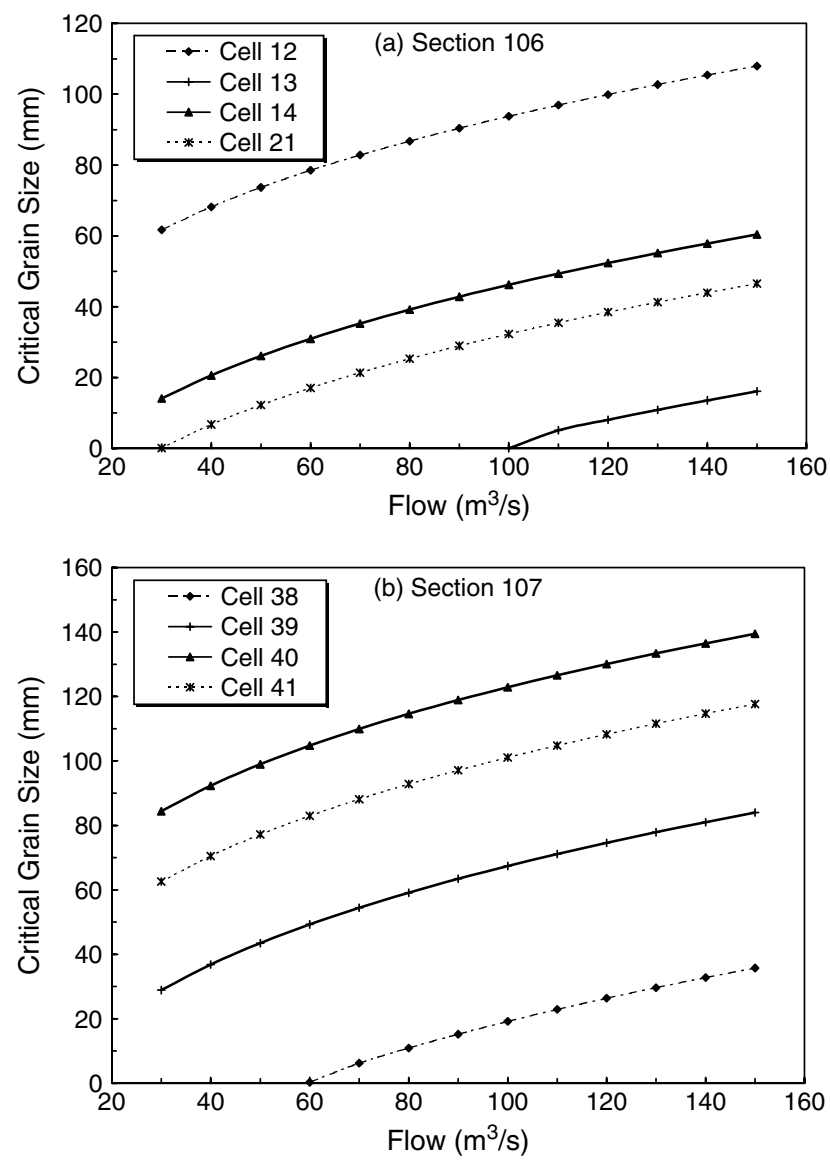

Figure 5. Relationships between critical grain size and flow for selected cells in (a) Section 106 and (b) Section 107

Table II. Critical grain sizes $(\mathrm{mm})$ in selected cells under various flows ${ }^{\mathrm{a}}$

\begin{tabular}{|c|c|c|c|c|c|c|c|c|}
\hline \multirow{2}{*}{$\begin{array}{l}\text { Flow } \\
\left(\mathrm{m}^{3} / \mathrm{s}\right)\end{array}$} & \multicolumn{4}{|c|}{ Section 106} & \multicolumn{4}{|c|}{ Section 107} \\
\hline & Cell 12 & Cell 13 & Cell 14 & Cell 21 & Cell 38 & Cell 39 & Cell 40 & Cell 41 \\
\hline 30 & 62 & Dry & 14 & $\mathbf{0}$ & Dry & 29 & 84 & 63 \\
\hline 40 & 68 & Dry & 21 & 7 & Dry & 37 & 92 & 71 \\
\hline 50 & 74 & Dry & 26 & 12 & Dry & 43 & 99 & 77 \\
\hline 60 & 79 & Dry & 31 & 17 & 0 & 49 & 105 & 83 \\
\hline 70 & 83 & Dry & 35 & 21 & 6 & 54 & 110 & 88 \\
\hline 80 & 87 & Dry & 39 & 25 & 11 & 59 & 115 & 93 \\
\hline 90 & 90 & Dry & 43 & 29 & 15 & 63 & 119 & 97 \\
\hline 100 & 94 & 0 & 46 & 32 & 19 & 67 & 123 & 101 \\
\hline 110 & 97 & 5 & 49 & 36 & 23 & 71 & 127 & 105 \\
\hline 120 & 100 & 8 & 52 & 38 & 26 & 75 & 130 & 108 \\
\hline 130 & 103 & 11 & 55 & 41 & 30 & 78 & 133 & 112 \\
\hline 140 & 105 & 14 & 58 & 44 & 33 & 81 & 137 & 115 \\
\hline 150 & 108 & 16 & 60 & 47 & 36 & 84 & 139 & 118 \\
\hline
\end{tabular}

${ }^{a}$ Bold signifies that the critical grain size is greater than the corresponding maximum bedload size (given in Table III). 


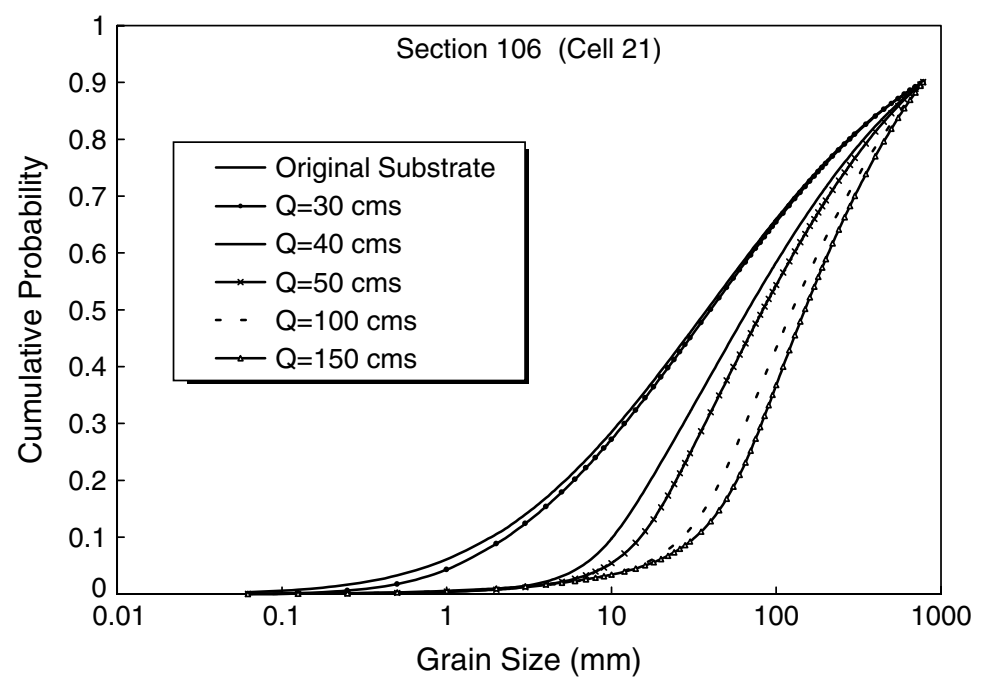

Figure 6. Grain size distributions of static armour layers for cell 21 in Section 106 under various flows
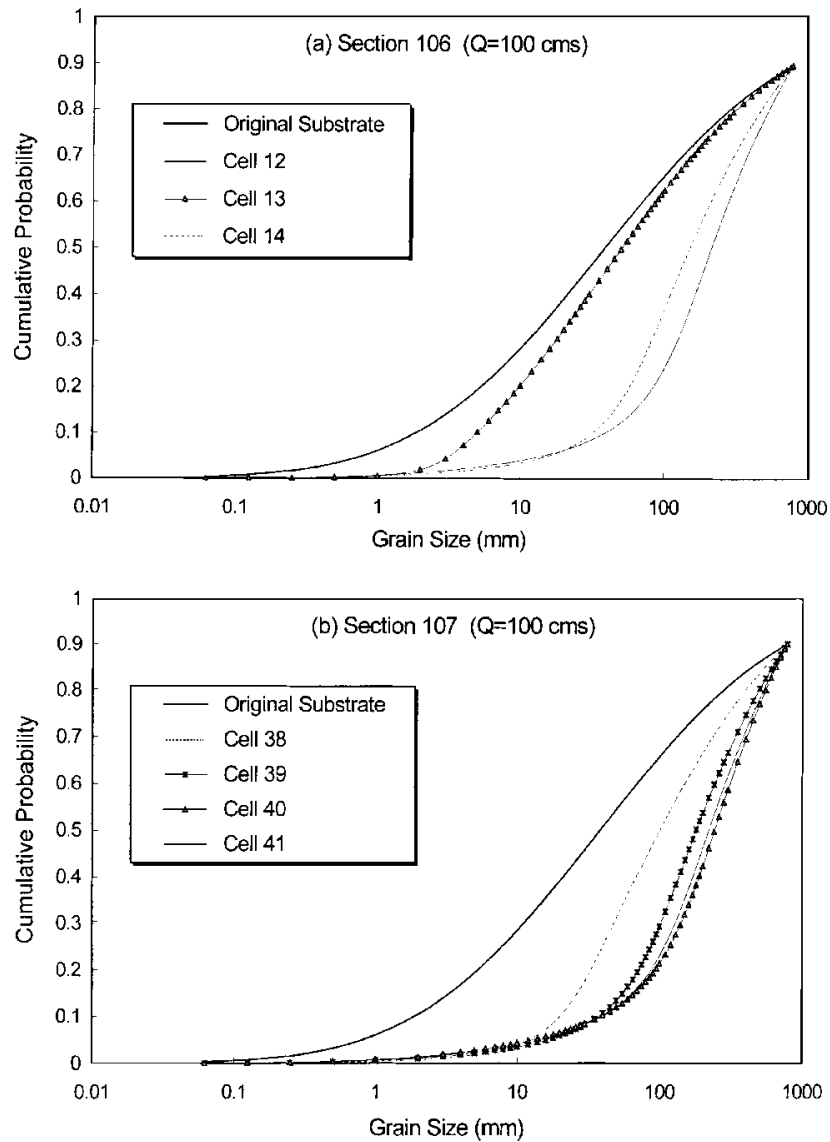

Figure 7. Grain size distributions of static armour layers for selected cells in (a) Section 106 and (b) Section 107 (flow $=100 \mathrm{~m}^{3} / \mathrm{s}$ ) 

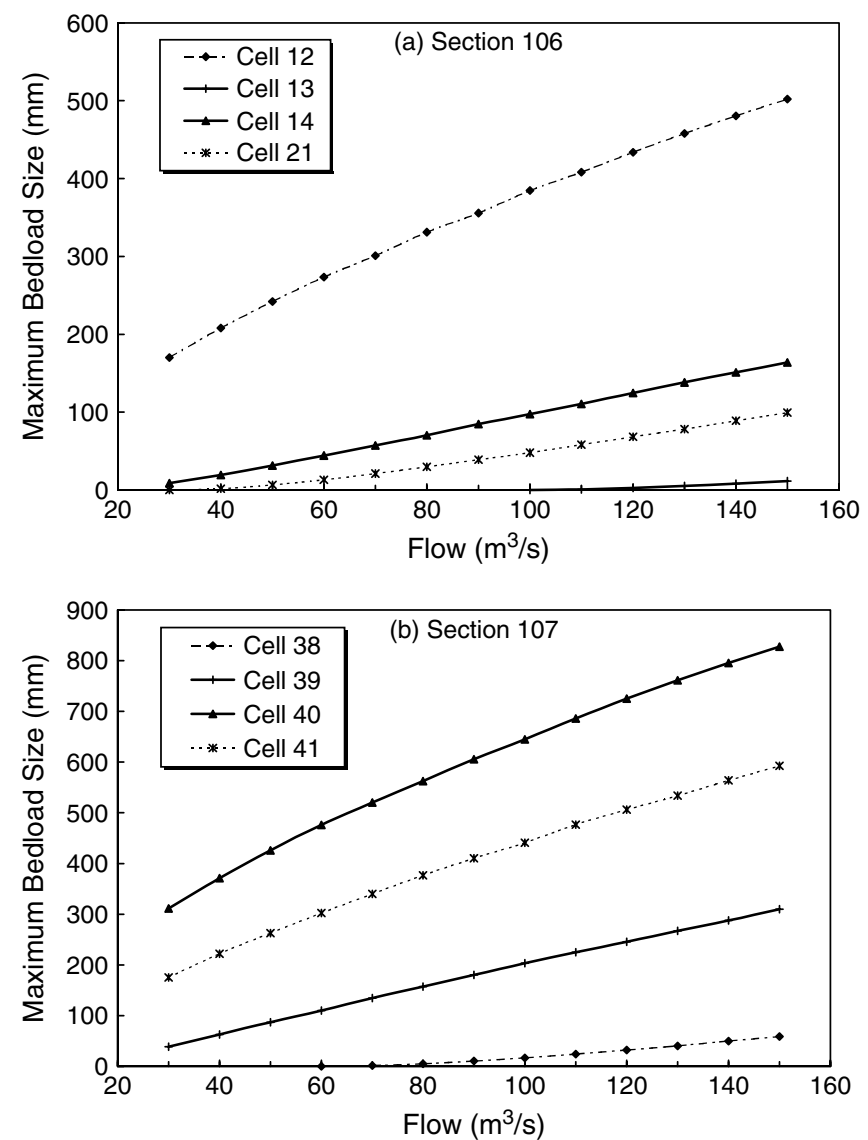

Figure 8. Relationships between maximum bedload size and flow for selected cells in (a) Section 106 and (b) Section 107

Table III. Maximum bedload sizes in selected cells under various flows (grain size in $\mathrm{mm})^{\mathrm{a}}$

\begin{tabular}{|c|c|c|c|c|c|c|c|c|}
\hline \multirow{2}{*}{$\begin{array}{l}\text { Flow } \\
\left(\mathrm{m}^{3} / \mathrm{s}\right)\end{array}$} & \multicolumn{4}{|c|}{ Section 106} & \multicolumn{4}{|c|}{ Section 107} \\
\hline & Cell 12 & Cell 13 & Cell 14 & Cell 21 & Cell 38 & Cell 39 & Cell 40 & Cell 41 \\
\hline 30 & 170 & Dry & 9 & 0 & Dry & 39 & 311 & 175 \\
\hline 40 & 208 & Dry & 19 & 2 & Dry & 63 & 371 & 222 \\
\hline 50 & 242 & Dry & 31 & $\overline{7}$ & Dry & 87 & 426 & 263 \\
\hline 60 & 273 & Dry & 44 & 13 & 0 & 110 & 476 & 302 \\
\hline 70 & 301 & Dry & 57 & 21 & 1 & 135 & 520 & 340 \\
\hline 80 & 331 & Dry & 70 & 30 & 5 & 157 & 563 & 377 \\
\hline 90 & 356 & Dry & 85 & 39 & 10 & 180 & 606 & 410 \\
\hline 100 & 385 & 0 & 97 & 48 & 17 & 203 & 645 & 441 \\
\hline 110 & 408 & 1 & 111 & 58 & 24 & 225 & 686 & 477 \\
\hline 120 & 434 & 3 & 125 & 68 & 32 & 246 & 725 & 506 \\
\hline 130 & 458 & 5 & 138 & 78 & 40 & 267 & 761 & 534 \\
\hline 140 & 481 & 8 & 151 & 89 & 50 & 288 & 795 & 564 \\
\hline 150 & 502 & 12 & 164 & 99 & 59 & 310 & 828 & 592 \\
\hline
\end{tabular}

${ }^{a}$ Bold signifies that the critical grain size (given in Table II) is greater than the corresponding maximum bedload size. 
sizes are smaller than $22 \mathrm{~mm}$ (see cells 13, 14, and 21 of Section 106, and cell 38 of Section 107). Such an outcome may be attributed to the fact that the entrainment criteria used in this study were derived for uniform sediment. In non-uniform sediment, the coarse particles on the bed are more easily entrained than the uniform sediment of equivalent sizes, because they have a higher chance of exposure to the flow. The situation is reversed for the fine particles on the bed due to the fact that they are more likely to be sheltered by the coarse particles (Wu et al., 2000). Thus when the incipient motion criteria for uniform sediment (such as those of Shields and Iwagaki) are used on non-uniform sediment, they tend to overestimate the critical grain sizes for the fine particles and underestimate those for the coarse particles. The median or mean grain size is frequently used as the reference size of the correction factor for the hiding and exposure effects (e.g. Bridge and Bennett, 1992; Wu et al., 2000). Our results indicate that $22 \mathrm{~mm}$ may be used as a reference size to distinguish the fine and coarse sediments when the threshold conditions for uniform sediment are employed to determine the critical shear stress for any size fraction of the non-uniform sediment. Such a reference size is beyond the scope of this study, hence future studies may be conducted to further address this issue.

Nominal grain size of stable substrate material. For schemes 1 and 2, the substrate status of each cell does not change with flow. The mean substrate grain size for scheme 2 (i.e. mean grain size of the original bed material) is constantly $86 \mathrm{~mm}$. However, for schemes 3, 4, and 5, the nominal grain sizes of the stable substrate change with flow. To illustrate this, the variations of nominal grain sizes (for cells 12 and 21 in Section 106) with flow are shown in Figure 9. The general trend revealed by these results is that the nominal grain size of the stable substrate increases with flow. The variation of the nominal grain size for scheme 5 is the steepest, while the curves for schemes 3 and 4 have similar trends. It is also shown in Figure 9 that the variation patterns of the curves for cells 12 and 21 are not quite the same, especially for the curve of scheme 5. For cell 12, the nominal grain sizes of scheme 5 are consistently larger than those of the other
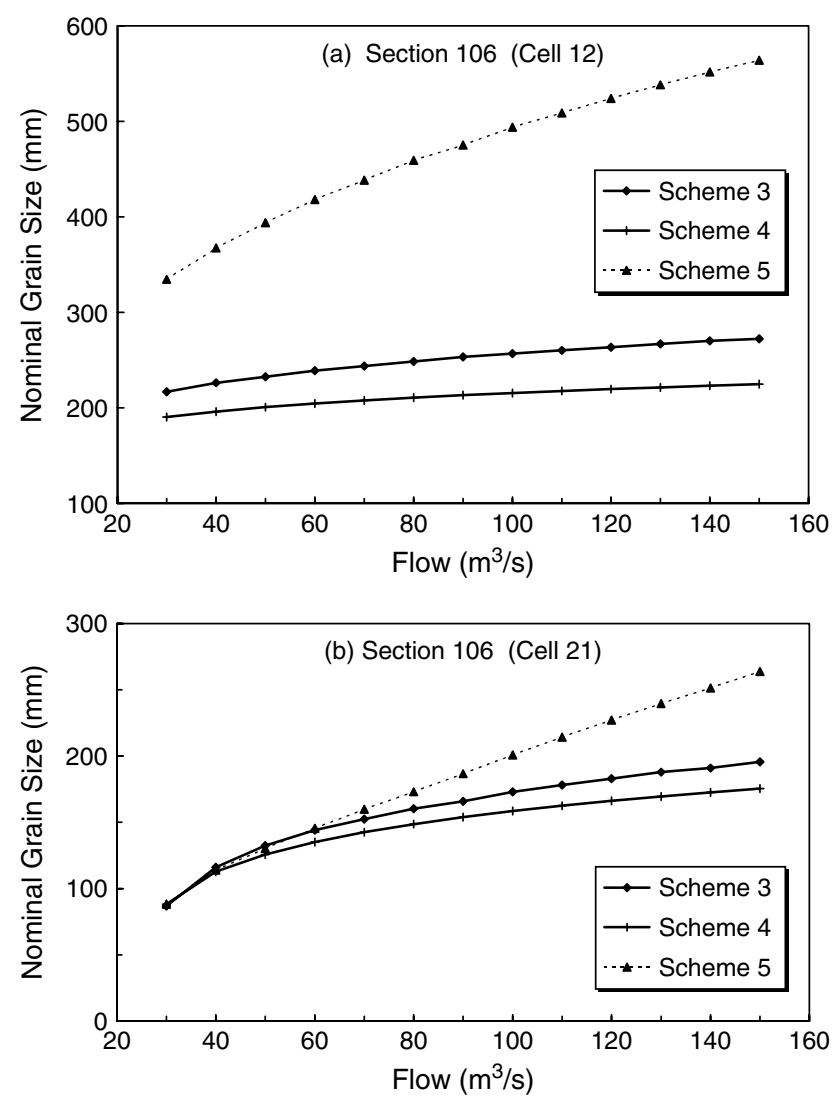

Figure 9. Relationships between nominal grain size and flow for various substrate schemes: (a) Cell 12 and (b) Cell 21 in Section 106 
two schemes. However, for cell 21, the nominal grain sizes of scheme 5 exceed those of scheme 3 only for the flows exceeding $60 \mathrm{~m}^{3} / \mathrm{s}$. Such a discrepancy is attributed to the different water depths at a given flow caused by the difference of cell geometry. For flows less than $60 \mathrm{~m}^{3} / \mathrm{s}$, the bed shear stresses induced by the relatively small depths in cell 21 are such that the maximum bedload sizes are finer than the estimated critical grain sizes (as pointed out in the preceding section). Hence, at these low flows, the nominal grain sizes of scheme 5 are smaller than the nominal sizes of scheme 3. On the other hand, the nominal grain sizes in cell 12 are nearly all greater than $200 \mathrm{~mm}$. The bulk sample shown in Figure 3 suggests that the $d_{80}$ size (or armour size) is between 200 and $300 \mathrm{~mm}$, which appears to agree with the predictions of schemes 3 and 4 , but not scheme 5 .

\section{Variation of physical habitat with flow}

Figure 10a displays the variations of WUA with flow for the five schemes used in the present study. At each simulation flow, the magnitudes of WUA increase following a consistent sequence, namely, scheme 2, 4 , 3,5 , and 1. Part of this sequence (i.e. scheme 4, 3, and 5) agrees with that shown in Figure 9. The substrate attributes specified in scheme 1 do not change with flow, but the substrate attribute differs for each cell. However, the mean grain size used in scheme 2 remains constant. The results shown in Figure 10a appear to indicate that the suitability values corresponding to the specified substrate attributes and the resulting physical habitat for scheme 1 are on the optimistic side, whereas the mean grain size of the original bed material tends to undervalue the suitability of the hydraulically worked substrate.
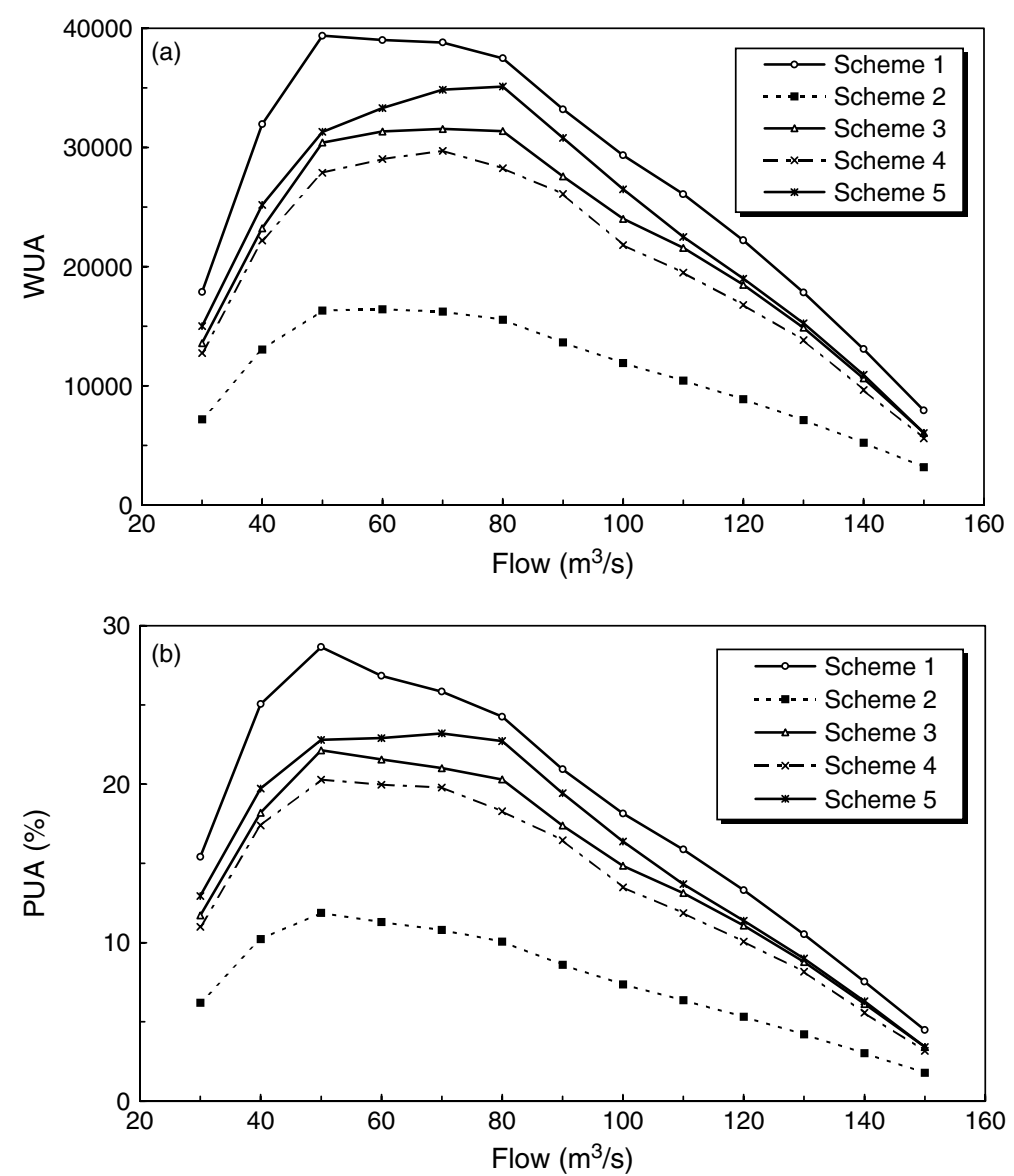

Figure 10. Variations of (a) WUA and (b) PUA with flow for various substrate schemes 
For schemes 1 and 2, the variations of WUA are only dependent upon the water velocity and depth but independent of the substrate status (as mentioned earlier). However, the variations of the substrate status, water velocity and depth are reflected by the WUA values for schemes 3, 4, and 5 . When the flows are less than $50 \mathrm{~m}^{3} / \mathrm{s}$, the cross-sectional average water velocity and depth are both on the rising limbs of the suitability curves. The suitability of the average water velocity reaches its maximum at $50 \mathrm{~m}^{3} / \mathrm{s}$ and then starts to fall, while the suitability of the average water depth continues to rise and reaches its maximum at about $80 \mathrm{~m}^{3} / \mathrm{s}$. Once the flow becomes greater than $80 \mathrm{~m}^{3} / \mathrm{s}$, the average water velocity and depth are both on the falling limbs of the suitability curves. Hence, the water velocity and depth are in phase as the flows are $<50 \mathrm{~m}^{3} / \mathrm{s}$ or $>80 \mathrm{~m}^{3} / \mathrm{s}$. The superimposition of these in-phase portions of the suitability curves results in the sharp variations of WUA with flow. However, in contrast to the dominance of the water velocity and depth in the above two ranges, the variations of WUA are more sensitive to the suitability of the stable substrate for flows between 50 and $80 \mathrm{~m}^{3} / \mathrm{s}$. Within this range, the WUA for scheme 3 (i.e. above-critical bed material) increases initially but then decreases at $70 \mathrm{~m}^{3} / \mathrm{s}$, although the WUA values are rather constant. The variation trend for scheme 4 (i.e. static armour) is similar to that for scheme 3 , but the gradients are steeper for scheme 4. The WUA for scheme 5 (i.e. stable armour material) increases monotonically with flow indicating that the suitability of the stable substrate is the dominating factor.

For comparison, the relationships between the percentage usable area (PUA) and the flow are demonstrated in Figure 10b, where PUA is defined as the ratio of WUA to the total wetted stream area in the simulation reach, i.e. PUA $=\mathrm{WUA} / \sum_{i} A_{i}$. The PUA may be interpreted as the proportion of the total wetted area that can be used as the physical habitat. From the functional perspective, the larger value of PUA represents the higher efficiency of the instream flow. Generally speaking, the results shown in Figure 10a and b are of similar patterns. The shapes of the curves in the two ranges dominated by the in-phase water velocity and depth are nearly identical, while the results for schemes 3 to 5 are quite different in the middle region. In this substrate-dominant region, the PUA values for schemes 3 and 4 decrease with flow, but the PUA for scheme 5 increases with flow and peaks at $70 \mathrm{~m}^{3} / \mathrm{s}$. Because the difference between the maximum and minimum PUA values for scheme 5 is less than $0.4 \%$ in the middle region, the PUA values for scheme 5 may well be treated as a constant (PUA $\cong 23 \%$ ). In Figure 10 a, the maximum WUA occurs at $50 \mathrm{~m}^{3} / \mathrm{s}$ for schemes 1 and $2,70 \mathrm{~m}^{3} / \mathrm{s}$ for schemes 3 and 4 , and $80 \mathrm{~m}^{3} / \mathrm{s}$ for scheme 5 . However, if the functional efficiency of the flow is concerned, the flow that results in the greater PUA can be viewed as a better option. For schemes 3 and 4, the differences between the maximum WUA and the WUA value corresponding to $50 \mathrm{~m}^{3} / \mathrm{s}$ are rather limited. Besides, the equilibrium partial armour layer simulated in scheme 5 only forms for the condition of steady sediment supply or steady partial transport of mixed-size sediment, neither of which is likely to be the normal case at the downstream of a barrier structure. With all that said, $50 \mathrm{~m}^{3} / \mathrm{s}$ may be recommended as an optimal instream flow to protect the target species.

In summary, this work uses five methods to evaluate substrate suitability in habitat simulation. The first method assumes that all substrate in the main channel is suitable. The second method bases substrate suitability on the mean grain size and assumes it is constant over the channel. The other methods evaluate the size of the stable bed material for the different flows. Despite the difference in the habitat area, the overall variation trends of the WUA (or PUA) curves for different evaluation schemes are similar, especially in the in-phase regions of water velocity and depth. However, a direct implication of the calculated physical habitat for the selected fish species is difficult to define. The relationship between physical habitat and the population of aquatic animals is not a simple one because physical habitat is a necessary condition but not a sufficient condition for the existence of a species or a collection of species (Milhous, 1999). The use of physical habitat requires consideration of other factors, such as the temporal variation of flows and the interactions between species and between life stages. These factors will jointly influence the state of the ecosystem and their effect remains to be investigated in future studies.

\section{ACKNOWLEDGEMENTS}

This study was supported, in part, by the National Science Council of the Republic of China (Grant No. NSC-89-2625-Z-002-004). The writers appreciate the help of R. T. Milhous in providing the source codes 
of PHABSIM. This work benefited from discussions with H. W. Shen, W. E. Dietrich, and G. Parker. The writers acknowledge Ian Jowett and an anonymous referee for reviewing the earlier version of this manuscript and offering many suggestions that are helpful for improving the clarity of the presentation.

\section{REFERENCES}

Bridge JS, Bennett SJ. 1992. A model for the entrainment and transport of sediment grains of mixed sizes, shapes, and densities. Water Resources Research 28: 337-363.

Buffington JM, Montgomery DR. 1999. Effects of sediment supply on surface textures of gravel-bed rivers. Water Resources Research 35: $3523-3530$.

Carling P. 1995. Implications of sediment transport for instream flow modelling of aquatic habitat. In The Ecological Basis for River Management, Harper DM, Ferguson AJD (eds). John Wiley: New York; 17-31.

Chin CO, Melville BW, Raudkivi AJ. 1994. Streambed armouring. Journal of Hydraulic Engineering ASCE 120: 899-918.

Dietrich WE, Kirchner JW, Ikeda H, Iseya F. 1989. Sediment supply and the development of the coarse surface layer in gravel-bedded rivers. Nature 340: 215-217.

Food and Agriculture Organization of the United Nations (FAO). 1998. Rehabilitation of Rivers for Fish, Cowx IG, Welcomme RL (eds). Fishing News Books: Oxford.

Gessler J. 1970. Self-stabilizing tendencies of alluvial channels. Journal of Waterways and Harbors Division ASCE 96: 235-249.

Gore JA, Hamilton SW. 1996. Comparison of flow-related habitat evaluations downstream of low-head weirs on small and large fluvial ecosystems. Regulated Rivers: Research and Management 12: 459-469.

Iwagaki Y. 1956. Hydrodynamical study on critical tractive force. Transactions of the Japanese Society of Civil Engineers 41: (in Japanese).

Jowett IG. 1997. Instream flow methods: A comparison of approaches. Regulated Rivers: Research and Management 13: 115-127.

Milhous RT. 1998. Modelling of instream flow needs: The link between sediment and aquatic habitat. Regulated Rivers: Research and Management 14: 79-94.

Milhous RT. 1999. History, theory, use, and limitations of the physical habitat simulation system. In Ecohydraulics 1999. Salt Lake City, Utah.

Milhous RT, Updike MA, Schneider DM. 1989. Physical habitat simulation system reference manual-Version II. Instream Flow Information Paper No. 26. Biological Report 89(16). US Fish and Wildlife Service: Washington, DC.

Nestler JM, Milhous RT, Layzer JB. 1989. Instream habitat modeling techniques. In Alternatives in Regulated River Management, Gore JA, Petts GE (eds). CRC Press: Boca Raton; 295-315.

Parker G, Sutherland AJ. 1990. Fluvial armour. Journal of Hydraulics Research 28: 529-544.

Petts GE. 1994. Rivers: dynamic components of catchment ecosystems. In The River Handbook. Hydrological and Ecological Principles, Vol. 2, Calow P, Petts GE (eds). Blackwell Scientific Publications: Oxford; 3-22.

Reiser DW, Ramey MP, Wesche TA. 1989. Flushing flows. In Alternatives in Regulated River Management, Gore JA, Petts GE (eds). CRC Press: Boca Raton; 91-135.

Shen HW, Lu JY. 1983. Development and prediction of bed armouring. Journal Hydraulic Engineering ASCE 109: 611-629.

Shields A. 1936. Application of similarity principles, and turbulence research to bed-load movement. California Institute of Technology: Pasadena (translated from German).

Statzner B, Higler B. 1986. Stream hydraulics as a major determinant of benthic invertebrate zonation patterns. Freshwater Biology 16: $127-139$.

Sutherland AJ. 1987. Static armour layers by selective erosion. In Sediment Transport in Gravel-bed Rivers, Thorne CR, Bathurst JC, Hey RD (eds). John Wiley and Sons: New York; 243-267.

Taiwan Endemic Species Research Center (TESRC). 1996. Taiwanese Endemic Species-Fish and Wildlife. Nantou: Taiwan (in Chinese).

Taiwan Endemic Species Research Center (TESRC). 1998. Annual Research Report-Habitat Research Group. Nantou: Taiwan (in Chinese).

Taiwan Provincial Water Conservancy Bureau (TPWCB). 1981. Chou-Shui Creek Flood Control Planning Report. Taichung: Taiwan (in Chinese).

Taiwan Provincial Water Conservancy Bureau (TPWCB). 1996. Chou-Shui Creek Regulation Planning Report. Taichung: Taiwan (in Chinese).

Watanabe M. 1983. A review of homalopterid fishes of Taiwan with description of a new species. Bulletin of the Biogeographical Society of Japan 38: 105-124.

Wilcock PR, McArdell BW. 1993. Surface-based fractional transport rates: mobilization thresholds and partial transport of a sand-gravel sediment. Water Resources Research 29: 1297-1312.

Wilcock PR, McArdell BW. 1997. Partial transport of a sand/gravel sediment. Water Resources Research 33: 235-245.

Wu W, Wang SSY, Jia Y. 2000. Nonuniform sediment transport in alluvial rivers. Journal of Hydraulics Research 38: 427-434. 